\title{
Načini održavanja strojeva i opreme ovisno o vrstama procesa proizvodnje obuće, odjeće i tekstila
}

\author{
Miroslav Mikulčić ${ }^{1}$, Željko Knezić2 ${ }^{\text {, Dubravko Rogale }}{ }^{2}$, Željko Penava² \\ JELEN PROFESSIONAL d.o.o., Čakovec ${ }^{1}$ \\ Sveučilište u Zagrebu Tekstilno-tehnološki fakultet ${ }^{2}$ \\ E-mail; zeljko.knezic@ttf.hr
}

DOI: $10.34187 / \mathrm{ko} .68 .4 .7$

\begin{abstract}
Sažetak:
Kvalitetno održavanje strojeva i opreme treba biti u funkciji pouzdanog odvijanja tehnološkog procesa, a koncipira se još u fazi izrade planova proizvodnje obuće, odjeće i tekstila. Zbog različitosti tehnoloških procesa proizvodnje obuće, odjeće i tekstila uočljive su razlike u metodici održavanja strojeva i opreme ovisno o vrsti tehnološkog procesa, ali i o načinu organiziranja tehničke pripreme proizvodnje kao i postupaka te strategija održavanja u okviru cijelog proizvodnog procesa. U radu su analizirani pristupi i strategije načina održavanja proizvodnih strojeva i opreme, proizvodnih linija, energetskih instalacija kao i pomoćne opreme nužne za ispravno odvijanje tehnoloških procesa. Obrađeni su aspekti i metodologija promptnog nesustavnog održavanja kao i strateškog preventivnog održavanja u poznatim hrvatskim tvornicama za proizvodnju tekstila, odjeće i obuće karakterističnih po višedesetljetnim proizvodnim uspjesima i uzoritim postupcima održavanja strojeva, opreme, proizvodnih linija i energetskih instalacija.
\end{abstract}

\section{Ključne riječi:}

održavanje strojeva i opreme, strategije održavanja, metode održavanja

\section{Summary:}

Quality maintenance of the machines and equipment should be in the function of reliable conduct of the technological process, and it is conceived in the phase of making plans for the production of footwear, clothing and textiles. Due to the diversity of technological processes of footwear, clothing and textile production, there are noticeable differences in the methodology of maintenance of machines and equipment depending on the type of technological process, but also on the method of organizing technical production preparation and procedures and maintenance strategies throughout the production process. The paper analyzes the approaches and strategies of the way of maintenance of production machines and equipment, production lines, energy installations as well as auxiliary equipment necessary for the proper conduct of technological processes. Aspects and methodology of prompt unsystematic maintenance as well as strategic preventive maintenance in well-known Croatian factories for the production of textiles, clothing and footwear, characterized by decades of production success and exemplary maintenance procedures of machines, equipment, production lines and energy installations, are discussed.

\section{Keywords:}

maintenance of machines and equipment, maintenance strategies, maintenance methods

\section{Uvod}

Razvojem promjena u društvu, međuljudskih odnosa, povećanjem potreba za većim izborom raznih dobara, stvara se i potreba pouzdanog opskrbljivanja tržišta određenim proizvodima. Neminovno je da sve u procesu proizvodnje bude planirano, „bez iznenađenja“. Zbog toga se poslije Drugog svjetskog rata sramežljivo nameće proučavanje procesa održavanja opreme i oblikovanje novog tehničkog područja. Tisuću devetsto sedamdesetih prvi put se pojavljuje termin terotehnologija (grč.: tereo - nauka o brizi za stvari). Životni vijek strojeva (opreme) može se promatrati iz različitih pozicija kroz vremenski period od trenutka uočavanja određene potrebe, (kad se počinje s projektiranjem), izrade, montaže, vremena eksploatacije (s održavanjem) i otpisom na kraju (zamjenom drugim, optimalnijim rješenjem). Ovisno, kako se analizira i zaključuje; vrijeme montaže također je jedan oblik održavanja, takozvanog investicijskog održavanja koje se može sjediniti s održavanjem u vrijeme korištenja opreme.

Tablica 1 Razlika između tradicionalnih i procesno orijentiranih poduzeća [1]

\begin{tabular}{|c|c|c|}
\hline OBILJEŽJA & $\begin{array}{c}\text { TRADICIONALNO } \\
\text { PODUZEĆE }\end{array}$ & $\begin{array}{c}\text { PROCESNO } \\
\text { PODUZEĆE }\end{array}$ \\
\hline Poslovni vidik & Poslovna funkcija & Poslovni proces \\
\hline Organizacijska jedinica & Odjel & Procesni timovi \\
\hline Radni zadaci, poslovi & Usko definirani & Fleksibilni i opsežni \\
\hline Fokus djelatnika & Nadređeni, rukovodioci & Kupci \\
\hline Naknada se temelji na & Provedbi aktivnosti & Postignutim rezultatima \\
\hline Uloga rukovodstva & Nadzor & Mentorstvo \\
\hline Ključna osoba & $\begin{array}{c}\text { Direktor odjela } \\
\text { poslovne funkcije) }\end{array}$ & $\begin{array}{c}\text { Vlasnik poslovnog } \\
\text { procesa }\end{array}$ \\
\hline Poslovna kultura & Nadređenost, konflikti & \begin{tabular}{c} 
Sudjelovanje, suradnja \\
\hline
\end{tabular}
\end{tabular}

\section{Organizacija proizvodnje}

\subsection{Orijentacija poduzeća}

Održavanje strojeva i opreme ovisno je o orijentaciji poduzeća, jer bitno se razlikuju tradicionalno od procesno orijentiranih poduzeća (tablica 1). Neovisno o orijentaciji poduzeća, postoje dva različita pristupa u planiranju proizvodnih procesa, odnosno, opterećenju strojeva tj. tehnoloških radnih mjesta:

a) Maksimalno opterećenje $(65-80 \%)$ radnog mjesta, to jest, predmet obrade čeka „da dođe na red“ (zapadnjačko razmišljanje)

b) Stroj čeka radni nalog (Japan)

\subsection{Vremenski dijagrami}

Za precizno i pouzdano odvijanje proizvodnje i svega vezanog uz proizvodnju neophodno je koristiti se vremenskim dijagramima (ili nekim njihovim slijednicima) kojima se planira i zorno prati: iskorištenja strojeva, iskorištenja radnog vremena, radnika, raspodjela poslova, planiranje proizvoda i radnih mjesta, opterećenja strojeva, tijek odvijanja planiranog. Planiranje treba biti fleksibilno, po potrebi mijenjati definirane ciljeve. Treba obuhvatiti sve dijelove i funkcije u skladnu cjelinu, a svakom pojedincu dodijeliti definirane zadatke, odgovornost i ovlasti, te definirane potrebne resurse.

\subsection{Organiziranje i vođenje procesa}

Organiziranjem u skladu s odgovarajućim normama i procedurama definira se najbolja organizacijska struktura i rješenja. Norme (standardi) propisuju funkcioniranje sustava i pojedinca, a procedurama se definiraju rješenja pri obavljanju zadataka. 


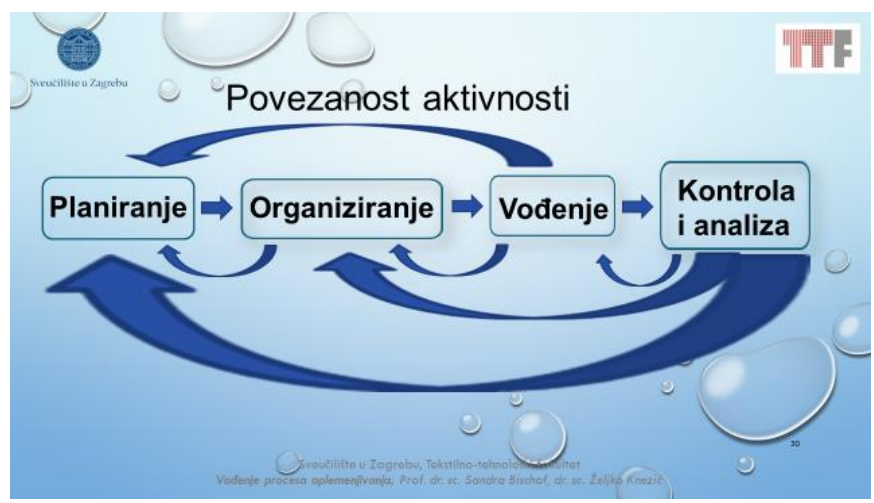

Slika 1. Povezanost aktivnosti planiranja, vođenja i kontrole proizvodnje[2]

Vođenje procesa je neprekidno djelovanje na parametre sustava s nakanom postizanja unaprijed zadanog cilja, a može se provoditi na više načina, npr.:

- jedan rukovoditelj, neprekidno prisutan, centralizirana prava odgovornost

- $\quad$ pravičan rukovoditelj s autoritetom je inicijator, disciplinirano osoblje izvršava unaprijed propisane zadatke, a pojedinac je podređen zajedničkim interesima

Vođenje procesa (dvosmjerna komunikacija)[2](sl. 1.): koordinacija osoblja (djelatnika), usmjeravanje, motivacija, iskorištenje postrojenja, energenti, pomoćni materijal, troškovi, praćenje rezultata rada, razvoj. Kontrola (povratna veza) - uspoređivanje ostvarenih rezultata s planiranim utvrđivanje odstupanja: kvaliteta proizvoda i obavljenih poslova, zalihe, financijski tokovi. Zbog efikasnijeg vođenja proizvodnog procesa procesi kontrole i planiranja moraju biti usko povezani.

\subsection{Razvoj održavanja strojeva i opreme}

Održavanje opreme je niz postupaka u funkciji proizvodnje koji bi se trebal poduzimati prema unaprijed pripremljenim planovima s ciljem smanjenja broja pojave kvarova kojima se prekida funkcionalno odvijanje tehnološkog procesa. Razvidno je da uz suvremeni pristup organiziranja sveobuhvatnih procesa u proizvodnji, može se jedinstvo funkcija održavanja i proizvodnje temeljiti na smjernicama:

- proizvodni ciklus sadržava mnoštvo aktivnosti izrade i održavanja,

- radnici održavanja su proizvodni radnici,

- $\quad$ održavanje ne postaviti kao uslužnu djelatnost, nego kao proizvodnu aktivnost, jer o održavanju ovise konačni rezultati,

- poslovi održavanja su multidisciplinarni te su potrebni stručni i visokoobrazovani kadrovi.

\begin{tabular}{|c|c|}
\hline STRUČNJACI ODRŽAVANJA & \multirow{2}{*}{$20 \%$} \\
\cline { 1 - 1 } KONSTRUKTORI & \\
\cline { 1 - 1 } KOMERCIJALISTI & \\
\cline { 1 - 1 } GRADITELJI OPREME & \\
\cline { 1 - 1 } MONTAŽERI & \\
\cline { 1 - 1 } STRUČNJACI ZA POUZDANOST & \\
\cline { 1 - 1 } PROGRAMERI ZA IZBOR &
\end{tabular}

Slika 2. Utjecaj sudionika na troškove održavanja[2]

Kvalitetno održavanje u razvijenim, modernim sustavima ima dugoročnu strategiju kojom se želi ostvariti: povećanje kvalitete izrade proizvoda uz veću produktivnost proizvodnje, smanjenje otpada u proizvodnji sprečavanje zagađenja okoliša, poštivanje planiranih rokova povećanjem motivacije za rad, zaštita od povreda na radu, racionalno iskorištenje energije i sirovina, uklanjanje nepredviđenih sustavnih pogrešaka, te nakon analize i prosudbe provesti poboljšanje strojeva i opreme. Održavanje nije samo sebi svrha, ne smije se zloupotrebljavati važnost, odnosno odgovornost sudionika u procesima održavanja (sl. 2). Ne smiju se zanemariti troškovi koji se ostvare, jer trebaju biti opravdani i vratiti se kroz ostvarene doprinose poboljšanja. Pedesete godine dvadesetog stoljeća bile su prijelomne u području održavanja. Naime, zbog sve intenzivnijeg razvoja industrijske proizvodnje i potrebe veće pouzdanosti proizvodnih sustava, dotadašnji pristup interventnog (korektivnog) održavanja popravka nakon nastanka kvara, ne ispunjava očekivanja. Svoje mjesto zauzima druga generacija održavanja u kojoj se obavlja preventivno održavanje u vremenski određenim terminima, sustavno se planira i uz pomoć glomaznih sporih računala. Dolazi do izražaja potreba za određenim kompetencijama u području održavanja. Sveobuhvatni intenzivan razvoj sve složenijih proizvodnih sustava u sedamdesetim i osamdesetim godinama dvadesetog stoljeća iziskuje potrebe pouzdanosti treće generacije održavanja temeljene na neprekidnom nadzoru stanja primjenom manjih računala. Obradom i analizom podataka utvrđuju se rizični faktori, kvarovi i proizvodni učinci, te se obavlja vođenje procesa u cilju povećanja kvalitete. Prema dostupnim podacima, pouzdanim informacijama, četvrta generacija održavanja prisutna je u razvijenim sustavima devedesetih godina dvadesetog stoljeća uočljivim investiranjem $\mathrm{u}$ održavanje usmjereno na proizvodne rezultate $\mathrm{s}$ glavnim karakteristikama: pregled upravljanja, timski rad, propisane norme (procedure), upravljanje performansama, vođenje brige o okolišu, obavezna tehnička dokumentacija, motivacijski pristup, potreba za certificiranim kompetencijama, moderni koncepti.

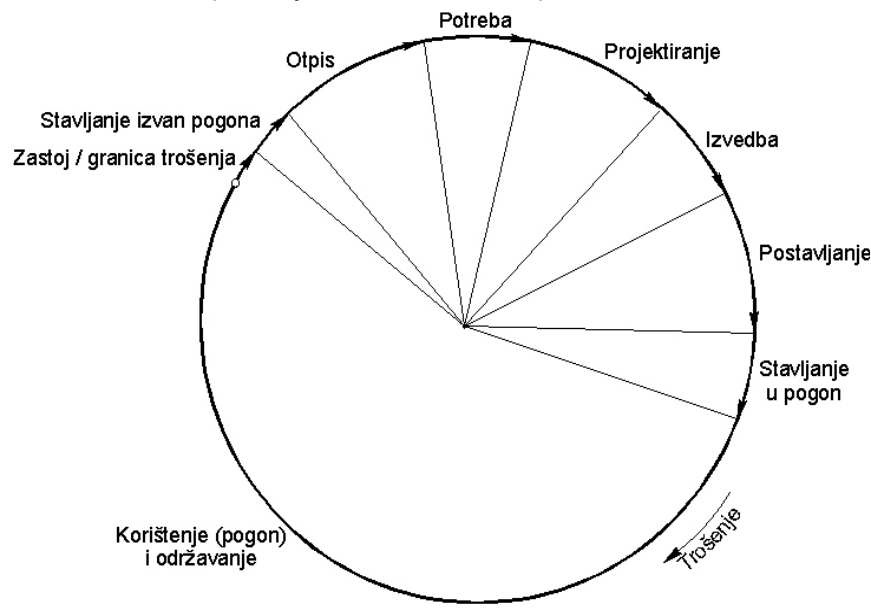

Slika 3. Faze opreme u životnom vijeku - Koncept: Terotehnologija (D. Parkes)[2]

\subsection{Izrada planova održavanja}

U izradi planova i troškova održavanja trebaju sudjelovati osobe koje dobro poznaju specifičnosti tehnološkog procesa proizvodnje, faze opreme u životnom vijeku (slika 3), a pri tom se treba voditi računa o nekoliko elemenata koji trebaju služiti kao smjernice:

a) snimak postojećeg procesa

b) strategija održavanja

c) koraci uvođenja povoljnijeg postupka održavanja.

\subsubsection{Snimak postojećeg procesa}

Kako bi se poduzeli odgovarajući koraci, potrebno je utvrditi stvarne pokazatelje procesa, (utrošeno vrijeme i troškove materijala za održavanje za svaki pojedini stroj - troškovnu jedinicu, stanje postrojenja i opreme i sve što utječe na ostvarivanje minimalizacije zastoja - prikazano na slici 4).

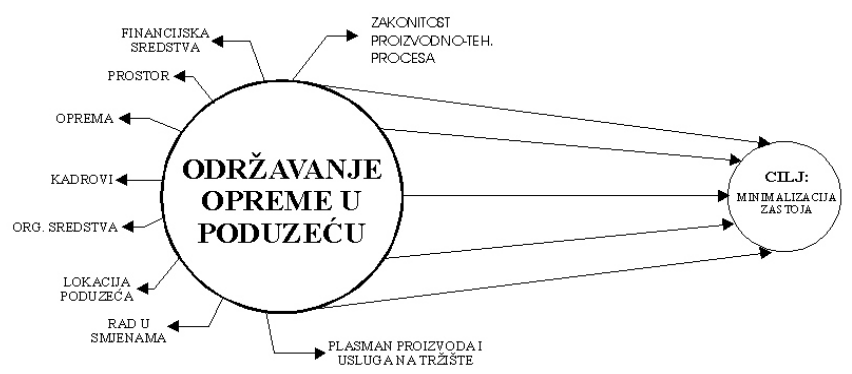

Slika 4. Utjecajni čimbenici na održavanje opreme pri ostvarivanju smanjenja zastoja[2] 


\subsubsection{Strategija održavanja}

Održavanje u proizvodnom procesu u tekstilnoj, odjevnoj i obućarskoj industriji treba biti prilagođeno proizvodnim ciklusima i potrebama tako da je što manje neplaniranog zaustavljanja strojeva i pozivanja majstora za popravke strojeva; te zbog toga održavanje treba promatrati kroz tri segmenta: preventivno, interventno, investicijsko. Da bi se ostvario kontinuitet u skladu s planom proizvodnje, održavanje je potrebno planirati tako da je težište na preventivi i investicijskom održavanju, a interventno tijekom vremena što više smanjivati. Investicijsko održavanje treba omogućiti pouzdaniju i kvalitetniju proizvodnju i veću produkciju.

\subsubsection{Preventivno održavanje}

Ako se već ne mogu u potpunosti izbjeći neplanirani zastoji, onda treba provoditi aktivnosti koje će in smanjiti: pravilno stručno rukovanje, održavanja čistoće, neprekidni elektronski nadzor (ako je moguće), te postupanje prema planu preventivnog održavanja. Planovi preventivnog održavanja izrađuje se za svaki stroj posebno na temelju proizvođačkih naputaka, analize učestalosti kvarova i problema koji se pojavljuju. Sadrže aktivnosti i postupke koje je nužno provesti u zadanim vremenskim terminima (dnevno, tjedno, mjesečno, godišnje) kako bi se preventivno uklonili uzroci kvarova. U plan preventivnog održavanja treba uvrstiti i vrijeme za uklanjanje mogućih većih kvarova koje su „osjetili“ senzori, a moguće ih je ukloniti u pogodnom trenutku. Preventivno održavanje provodi se sukladno planovima održavanja u dogovoru sa organizatorom proizvodnje. Za svaki proizvodni odjel osim odgovornog voditelja proizvodne, određen je broj stručnih radnika koji rade na zadacima preventivnog održavanja i svakodnevno provode aktivnosti i zahvate propisane planom preventivnog održavanja. Stručnu pomoć (ako je potrebna) pri rješavanju tehnoloških i tehničkih problema ili postupaka koji sprječavaju nastajanje kvara, obavljaju posebni stručni timovi. Evidenciju preventivnog održavanja sukladno planovima održavanja i propisanim obrascima provode sami izvršioci, a ovlaštene osobe (navedene u „Planu“), kontroliraju provedbu održavanja, poštivanje zahtjeva plana preventivnog održavanja, te evidentiranje provedenog $\mathrm{i}$ ispravnost postrojenja.

\subsubsection{Interventno održavanje}

Usprkos svemu poduzetom za smanjenje broja neplaniranih zastoja, oni se ipak pojave, te prema statističkim pokazateljima treba planirati vrijeme izvršioce. Stoga je potrebno da se kvalitetno u što kraćem roku ukloni (ispravi) razlog nastanka zastoja. Zbog toga se uz unaprijed propisanu proceduru primjenjuje i poseban sustav za obavještavanje odgovornih i zaduženih za uklanjanje zastoja o nastalom kvaru, te evidenciji svega: tko, što, kada i koliko treba do nastavljanja proizvodnog procesa. Da bi se racionalno poslovalo i objektivno donosile odluke o redoslijedu izvođenja radova unaprijed su utvrđeni kriteriji za određivanje hitnosti (Tablice 2a i b).

Tablice 2. a) Vrijednosti relativne važnosti postrojenja,

\begin{tabular}{|c|l|}
\hline Vrijednost & \multicolumn{1}{|c|}{ Opis } \\
\hline 1 & $\begin{array}{l}\text { Centralna energetska postrojenja koja opskrbljuju više } \\
\text { proizvodnih procesa }\end{array}$ \\
\hline 2 & $\begin{array}{l}\text { Važna proizvodna postrojenja čiji zastoj će izazvati zastoj } \\
\text { više od 60\% kapacitet proizvodnje }\end{array}$ \\
\hline 3 & $\begin{array}{l}\text { Druga važna postrojenja čiji zastoj će izazvati zastoj od } \\
30 \% \text { kapaciteta proizvodnje }\end{array}$ \\
\hline 4 & $\begin{array}{l}\text { Ostala postrojenja, strojevi čiji zastoj će izazvati zastoj do } \\
30 \% \text { kapaciteta proizvodnje }\end{array}$ \\
\hline 5 & $\begin{array}{l}\text { Sredstva unutarnjeg transporta korištena u proizvodnom } \\
\text { procesu }\end{array}$ \\
\hline 6 & $\begin{array}{l}\text { Strojevi, postrojenja za proizvodnju sporednih proizvoda } \\
\text { (pomoćni materijal) }\end{array}$ \\
\hline 7 & $\begin{array}{l}\text { Strojevi, postrojenja pomoćnih pogona (kuhinja, } \\
\text { restoran...) }\end{array}$ \\
\hline 8 & Izrada dijelova strojeva, uređaja za zalihu \\
\hline 10 & Infrastruktura potrebna za proizvodnju \\
\hline & Ostala infrastruktura \\
\hline
\end{tabular}

b) Vrijednosti relativne važnosti vrste radova

\begin{tabular}{|c|l|}
\hline Vrijednost & \multicolumn{1}{|c|}{ Opis } \\
\hline 0 & Opasnost od povreda ljudi \\
\hline 1 & Zastoj ili ispad koji treba otkloniti \\
\hline 2 & $\begin{array}{l}\text { Opasnost, kada zbog napredovanja oštećenja može doći } \\
\text { do zastoja u proizvodnji ili smanjenja kvalitete }\end{array}$ \\
\hline 3 & Preventivno održavanje \\
\hline 4 & $\begin{array}{l}\text { Pomoćni radovi za proizvodnju koji se obavljaju u } \\
\text { proizvodnom ciklusu (izmjena alata) }\end{array}$ \\
\hline 5 & $\begin{array}{l}\text { Aktivnosti uklanjanja slabih mjesta. Proizvodnja dijelova } \\
\text { za skladište, ako ih više nema na skladištu }\end{array}$ \\
\hline 6 & $\begin{array}{l}\text { Neplanirani radovi za vrijeme planiranog zastoja } \\
\text { postrojenja }\end{array}$ \\
\hline 7 & $\begin{array}{l}\text { Proizvodnja planiranih dijelova za skladište kojih već ima } \\
\text { na zalihi, održavanje i popravak alata i sredstava službe } \\
\text { održavanja }\end{array}$ \\
\hline 8 & $\begin{array}{l}\text { Poboljšanja na proizvodnim postrojenjima, uređajima } \\
\text { (povećanje kapaciteta, kvalitete, pouzdanost u radu...) }\end{array}$ \\
\hline 9 & $\begin{array}{l}\text { Racionalizacije koje služe smanjenju troškova, a nisu } \\
\text { prethodno spomenute }\end{array}$ \\
\hline 10 & $\begin{array}{l}\text { Radovi na uređenju (dodatno čišćenje, bojenje...) radnih I } \\
\text { ostalih prostora }\end{array}$ \\
\hline & \\
\hline &
\end{tabular}

Prioritet ima zahvat na opremi koja ostvari manji umnožak vrijednosti iz tablica a i b.

\subsubsection{Investicijsko održavanje}

Investicijsko održavanje su aktivnosti koje se provode s ciljem poboljšanja, modernizacije postojećih postrojenja i procesa, ugradnja novih postrojenja i uvođenje novih procesa. Remonti su posebna, složena grupa aktivnosti koje se mogu svrstati u područje preventivnog održavanja, ali i u područje investicijskog održavanja. Iz navedenog proizlazi da se to područje aktivnosti treba isplanirati uključujući sve bitne elemente.

Sveobuhvatni posao pouzdano se može obaviti izradom Ganttovih karata, (grafičkim prikazom terminskog plana remonta, tablica 3). Postoje i različiti računalni programi koji „odrađuju“ sličan posao, ali bez obzira na koji način se izrađivali, nužno je izraditi plan remonta koji sadrži:

- popisa radova i procjena radnog vremena i troškova,

- razrađenu pripremnu dokumentaciju s utvrđenim brojem izvršioca poslova,

- $\quad$ usklađenje broja izvođača po danima i utvrđivanje potrebnog broja izvođača,

- konačan popis poslova remonta i razrađena radna dokumentacija,

- $\quad$ pripremu i provjeru materijala s radioničkom pripremom,

- $\quad$ izvođenje remonta i završetak radova [4]

\subsection{Metode održavanja}

Svaka tvrtka teži da posluje sa što manjim zastojima - kvarovima strojeva u proizvodnji te sa što nižim troškovima. $U$ tome smislu održavanje radnih sredstava mora biti ekonomično, a istovremeno kvalitetno kako bi tvrtka bila konkurentna na tržištu. Ekonomičnost i kvaliteta održavanja strojeva ovise i o samom izboru održavanja. [5]

\subsubsection{Metodologija uvođenja sustava održavanja ( moderan koncept)}

- Izbor sustava i odabir podataka,

- utvrđivanje granica sustava,

- opis sustava i funkcionalni dijagram tijeka,

- funkcije i greške u sustavu,

- analiza grešaka i njihov utjecaj,

- logična analiza stabla kvara,

- $\quad$ selekcija naloga tj. zadataka. 
Tablica 3. Obrazac - Godišnji terminski plan radova remonta[4]

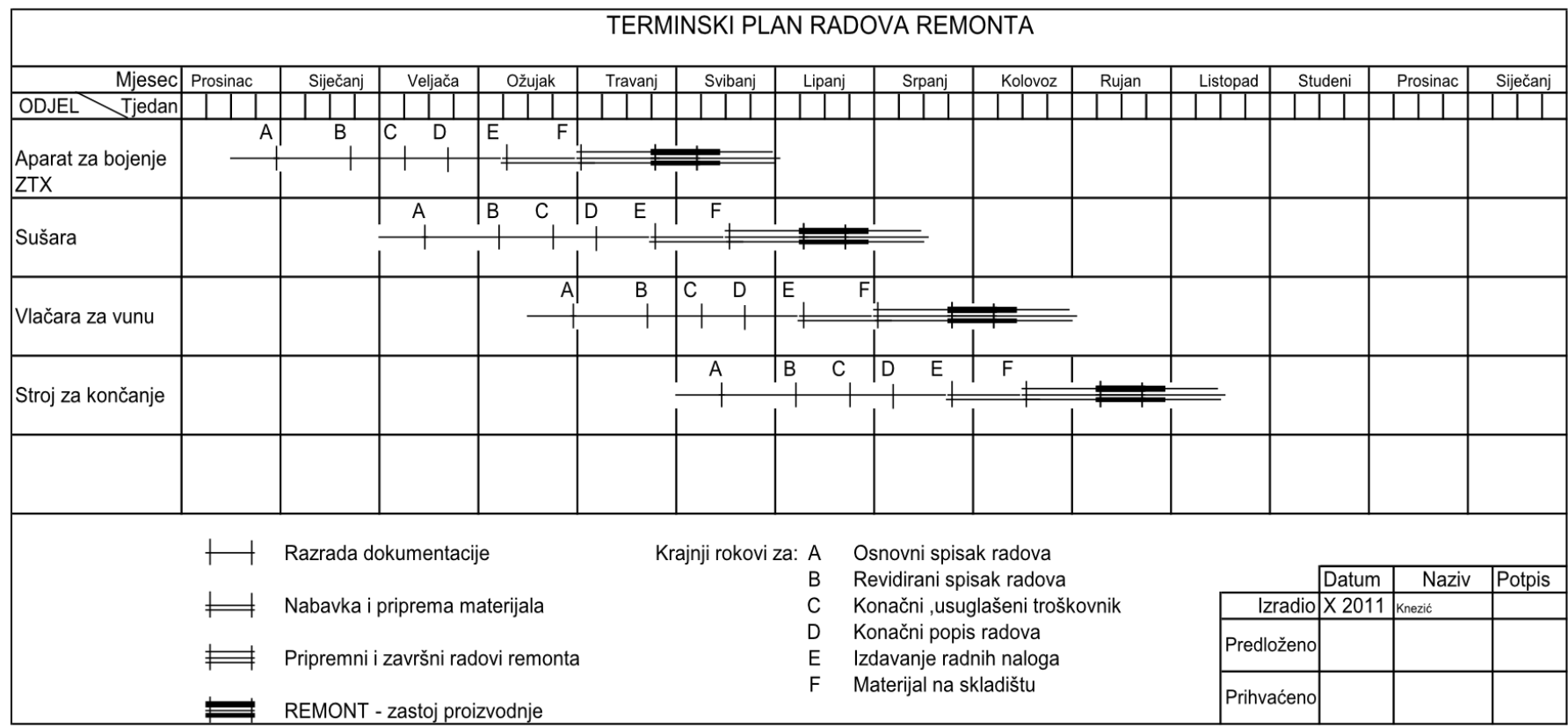

\subsubsection{Cjelovito produktivno održavanje TPM}

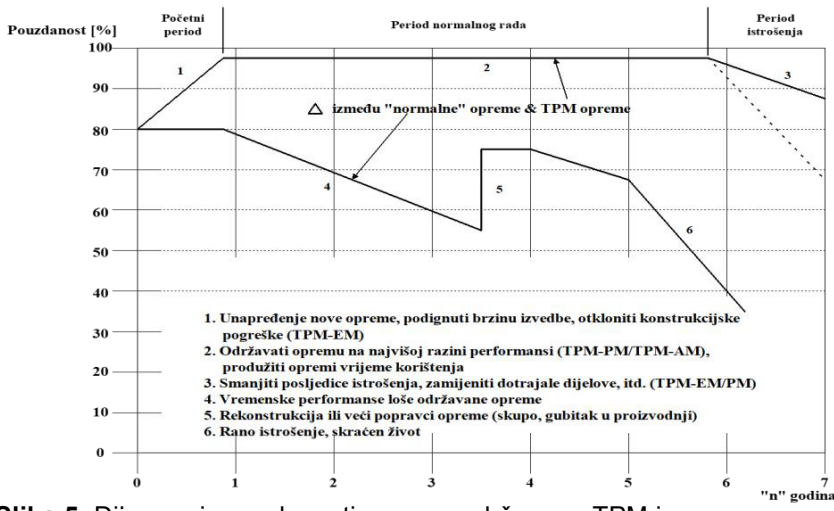

Slika 5. Dijagrami pouzdanosti opreme održavane TPM i „tradicionalno"[1]

Cjelovito produktivno održavanje (Total Productive Maintenance) ima dvije definicije:

- Japanska definicija:

"TPM je cjelovito učinkovito održavanje koje uključuje potpuno sudjelovanje svih" "......svaki pojedini radnik sudjeluje......." Seiichi Nakajima: JIPM (Japan Institute of Plant Maintenance - japanski institut za održavanja u industriji)

- "Zapadnjačka" definicija:

"TPM konstantno poboljšava sveukupnu učinkovitost opreme, s aktivnim uključivanjem rukovatelja" - Edward Hartman: Internacionaln TPM institut, Inc.[1]

Važno je napomenuti da TPM i u početnom periodu korištenja strojeva opreme neprekidnim poboljšanjima povećava pouzdanost (sl. 5) i učinkovitim timskim radom, kontinuiranim razvojem vještina za rukovatelje strojeva i stručnjake održavanja.

Tablica 4. Plan preseljenja tvrtke 1

\section{Opis tvrtki}

\subsection{Prva tvrtka}

Prva tvrtka više od sedamdeset godina serijski proizvodi visoko kvalitetnu obuću. Industrijski način proizvodnje obuće zahtjeva temeljitu pripremu proizvodnog procesa uz učinkovito povezivanje: ljudi, vremena, strojeva, proizvodnog prostora, materijala... Svaka obuća, bilo da se radi o dječjoj, ženskoj ili muškoj trebala bi biti: visoke kvalitete izrade i dizajna, udobna, od kvalitetnih prirodnih ili umjetnih materijala. Kvalitetno izrađena obuća uvelike ovisi o strojevima koje posjeduje tvrtka te stručnom kadru koji te strojeve poslužuje i održava.

Veliku ulogu kod udobnosti obuće ima kalup prema kojem se izrađuje određena obuća i stopalo koje će nositi tu obuću, jer svaki kalup ne odgovara svakom stopalu. Zato se danas sve više izrađuje obuća koja ima jednu dužinu a više širina: npr. veličina 42, širina u predjelu pregiba prstiju može biti od 7 do 12 , a po potrebi i šire.

\subsubsection{Tvrtka 1 - Održavanje}

Zbog specifičnosti proizvodnje i zahtjevnosti poslova na pojedinim radnim mjestima dogovoreno je da radnica za strojem zaustavi stroj i pozove voditelja odjeljenja ako uoči nepravilan radi. Ukoliko voditelj odjeljenja utvrdi nepravilan rad stroja, poziva određenog majstora specijalistu iz mehaničke radionice koji detektira kvar na stroju, te ako je moguće, u što kraćem roku dovodi stroj $u$ ispravno stanje. No, ukoliko kvar nije moguće otkloniti $u$ razumnom vremenu, pokvareni stroj zamijeni se identičnim ispravnim strojem. Stroj se nakon popravka u radionici ili nekoj vanjskoj specijaliziranoj instituciji ostavlja u pripravnosti.

\subsubsection{Tvrtka 1 - Preseljenje}

S ciljem kvalitetnije i profitabilnije proizvodnje, uprava tvrtke donijela je odluku o preseljenju proizvodnog pogona na novu lokaciju. Obavljena je detaljna analiza, te izrađeni kvalitetni sveobuhvatni planovi preseljenja u kojima su uzeti u obzir svi relevantni čimbenici (i popis svih radova koji će se obavljati tijekom preseljenja) (tab.4)

\begin{tabular}{|c|c|c|c|c|}
\hline \multicolumn{5}{|c|}{ PLAN PRESELJENJA } \\
\hline & Radne jedinice & Potreban broj djelatnika & Faza 1 Trajanje: 6 dana & Faza 2 Trajanje: 4 dana \\
\hline 1. & Djelatnika iz proizvodnje & 12 & \multirow{4}{*}{$\begin{array}{c}\text { Deinstaliranje svih strojeva } \\
\text { (krojnica, šivaonica, montaža, } \\
\text { skladište), pakiranje istih i } \\
\text { materijala te odvoz na novu } \\
\text { lokaciju }\end{array}$} & \multirow{4}{*}{$\begin{array}{l}\text { Instalacija strojeva u radnim } \\
\text { jedinicama, preslagivanje } \\
\text { materijala u skladištu }\end{array}$} \\
\hline 3. & Skladišni radnici & 3 & & \\
\hline 4 & Prijevozno sredstvo kamion & 4 & & \\
\hline & Voditelj nabave & 1 & & \\
\hline
\end{tabular}


Pri izradi vremenskih dijagrama vođena je briga o potrebi kontinuiteta proizvodnje zbog poštivanja rokova isporuke kupcima. Uz dodatne napore, to je ostvareno.

Tablica 5. Vremenski dijagram aktivnosti iz Plana preseljenja tvrtke 1

\begin{tabular}{|c|c|c|c|c|c|c|c|c|c|c|c|c|}
\hline \multicolumn{13}{|c|}{ PLAN PRESELJENJA } \\
\hline Vrijeme: & & $\begin{array}{c}30 \\
\text { dana }\end{array}$ & 1. & 2. & 3. & 4. & 5. & 6. & 1 . & 2. & 3. & 4. \\
\hline Odjel: & Krojnica & $\mathrm{A}$ & & - & $=-$ & $=$ & - & - & $\bullet$ & & & \\
\hline Odjel: & Šivaonica & A & & & & & & & $\cdots$ & $>$ & & \\
\hline Odjel: & Montaže & A & & & - & & & & & & & \\
\hline Odjel: & Skladište & A & & & & & & & & & & \\
\hline
\end{tabular}

A organizacijske pripreme u trajanju od 30 dana

B Deinstaliranje strojeva

C Pakiranje strojeva i materijala

D Odvoz strojeva

E Odvoz materijala

F Raspakiravanje strojeva

$\mathrm{G}$ Instalacija strojeva i preslaganje materijala

\subsection{Druga tvrtka}

KOTKA konfekcija dioničko društvo Krapina osnovano je 1954. godine. Zapošljava (u dvije smjene) oko 800 dobro educiranih, motiviranih poslu privrženih djelatnika, koji svojim znanjem uz najkvalitetnije stručnjake, iz teorije i prakse, u zemlji i inozemstvu, te stručan i poduzetan menadžment, suvremenom organizacijom, izrađuju cca 850 sakoa i 700 muških hlača dnevno. Važno je napomenuti da su to proizvodi najviše kvalitete prepoznatljivi na najvećim svjetskim sajmovima mode, a $95 \%$ instaliranih kapaciteta prodaje se $\mathrm{u}$ inozemstvu. Naime, konstantna prisutnost na izvoru informacija o dostignućima u razvoju tehnologije i organizacije rada, uska specijaliziranost, fleksibilnost i visoka kvaliteta muške odjeće rezultat su neprekidnih istraživanja i suradnje sa ekspertima Tekstilno-tehnološkog fakulteta Sveučilišta u Zagrebu te sa specijaliziranim institucijama iz inozemstva. Sve do sada učinjeno implementirano u planove za budućnost, utvrđuju nastojanje za bolje uvjete rada, veću razinu kvalitete i veću produktivnost u cilju povećanja konkurentnosti na inozemnom i domaćem tržištu, uz ostvarenu sigurnost i partnerstvo s kupcima i radnicima.[6]

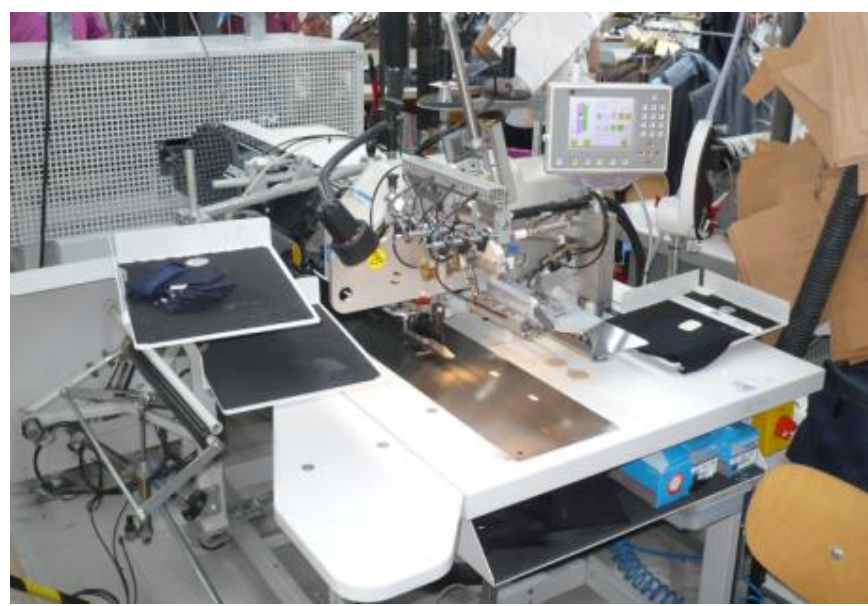

Slika 6. Šivaći automat

Kroz cca. 160 operacija neophodan je i ručni rad kojim se iz 170 dijelova izradi muško odijelo iz tkanina visoke kvalitete, savršenih krojeva, u kojima se muškarac ugodno osjeća i lijepo izgleda. Stručnjaci tvrtke s ponosom ističu kako u serijskoj proizvodnji izrađuju visoko kvalitetna odijela za najzahtjevnije kupce, a na identičan način tako rade i šivanje odijela prema specijalnim pojedinačnim narudžbama - šivanje po mjeri pojedinca.

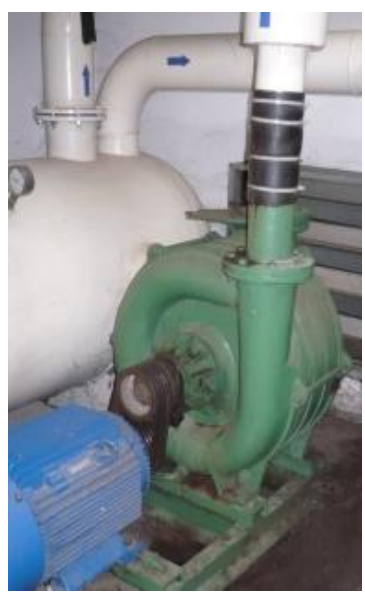

a)

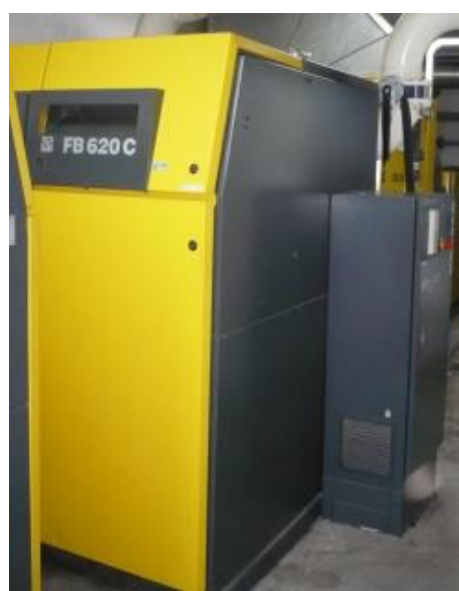

b)
Slika 7. a) Klasična rotaciona vakuum pumpa, b) Vijčana vakuum pumpa

Brigu o smanjenju zagađenja okoliša, nedostatku energije, povećanje troškova za energente, a posebno alarmantno stanje u niskoakumulativnoj, radno intenzivnoj proizvodnji tekstila - izradi odjeće, poticaj su za pronalaženja rješenja koja daju pozitivne efekte u današnjoj teškoj situaciji. Važno je napomenuti da samo onda kada menadžment firme prepozna bit problema, moguće je u nekoj sredini izraditi temeljitu analizu, te primijeniti provjerena tehnička dostignuća i metode rada, koja će dugoročno omogućiti opstanak kvalitetnih programa.

\subsubsection{Analiza i rezultati ulaganja}

Pregledom tvornice i prikupljenim podacima dobio se uvid u odvijanje tehnološkog procesa, uvjete u kojima rade radnice sa strojevima, karakteristike strojeva, podatke o građevini, instalacijama, energentima, postrojenja za proizvodnju pare - parni kotlovi... Podaci o troškovima električne energije potaknuli su na detaljnu analizu trošila i ostvarenih modifikacija s ciljem smanjenja opterećenja električne mreže, smanjenja troškova održavanja, te smanjenja ukupnog troška i konačno smanjenja 
onečišćenja okoliša. Nabavkom moderne opreme (slike $7 \mathrm{~b}, 8$ ) riješen je problem hlađenja proizvodnog prostora $u$ toplijim mjesecima od travnja do rujna), kad su više temperature vanjskog zraka, a osim strojeva koji zrače toplinom, prostor su zagrijavala i rasvjetna tijela s fluorescentnim cijevima (zbog starijeg tehničkog rješenja s klasičnom induktivnom prigušnicom).

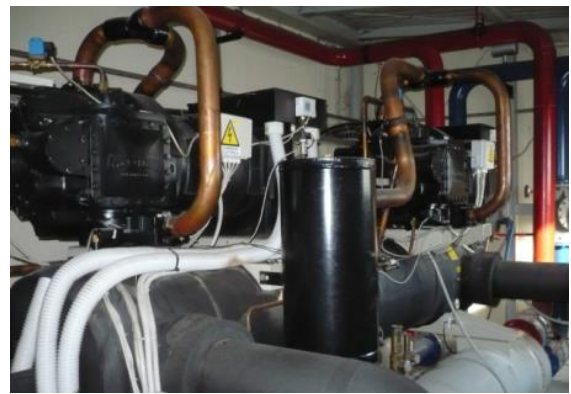

a)

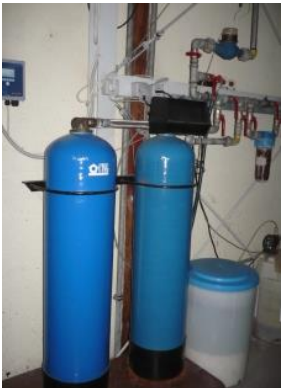

b)
Slika 8. a) Rashladno postrojenje, b) Automatska priprema meke vode

U tvornici Kotka konfekcija d.d. Krapina rukovodstvo je uočilo važnost primjene kvalitetnih tehničkih dostignuća i metoda u proizvodnim ciklusima, te je u skladu $\mathrm{s}$ utvrđenim ciljem posljednjih godina investirano je u razvoj vlastitih robnih marki, školovanje stručnih djelatnika, te nabavku modernih strojeva (sl. 6), uređaja i izradu instalacija. Sve je rađeno smišljeno, odmjereno u skladu s mogućnostima, nakon sveobuhvatne analize, te je uočljiva opravdanost ulaganja (i povrat kroz ostvarene uštede) u modificiranje (ili zamjene) strojeva, uređaja, rasvjetnih tijela...čime su se poboljšali radni uvjeti i smanjili izdaci za potrošenu energiju i rezervne dijelove. Smanjio se i opasni otpad - nema fluorescentnih cijevi, zamjenom peterostruko trajnijim LED rasvjetnim cijevima, sa oko tri puta manjom potrošnjom električne energije (tab.6). Višegodišnja suradnja tima stručnjaka različitih struka s praktičnim iskustvom primjene isplativih rješenja uštede energenata i smanjenja onečišćenja okoliša rezultirala su vraćanjem uložena sredstva u naznačenim periodima.

\subsubsection{Održavanje u Kotki}

Stručno rukovodstvo neprekidno educira radnice za strojevima da cijene svoje i tuđe radne vještine, materijal od kojeg nastaju ekskluzivna odijela strojeve s kojim rade. Od nasušne je važnosti da razumiju što rade, te da same mogu obaviti podešavanja, korekcije parametara pri promjeni materijala (sl. 9). Usmjerava ih se da „osluškuju“ stroj i da reagiraju na promjene. Nadređenog zovu onda kad same utvrde da razlog zastoja nadilazi njihove mogućnosti. Ako i on utvrdi da stroj nepravilno radi, zove majstora iz radionice koji detektira kvar na stroju i obavi popravak. Ukoliko kvar nije moguće brzo otkloniti, dovozi se ispravni stroj, a neispravni se transportira u radionicu ili vanjski servis gdje se popravi i ostavlja u pripravnosti. Po potrebi, naročito pri instalaciji i „uhodavanju“ novih strojeva i sustava, angažiraju se eksperti od strane proizvođača da svoje znanje prenesu radnicama, rukovoditeljima proizvodnih linija i djelatnicima održavanja. Povremeno se na stručne skupove, sajmove, izložbe upućuju kvalitetniji djelatnici, rukovodioci i stručnjaci da se upoznaju s novitetima i trendovima razvoja, te dostignućima drugih. Neprekidno djelatnike potiču na usavršavanje i podržavaju in u želji za nastavak obrazovanja i usavršavanja u struci.

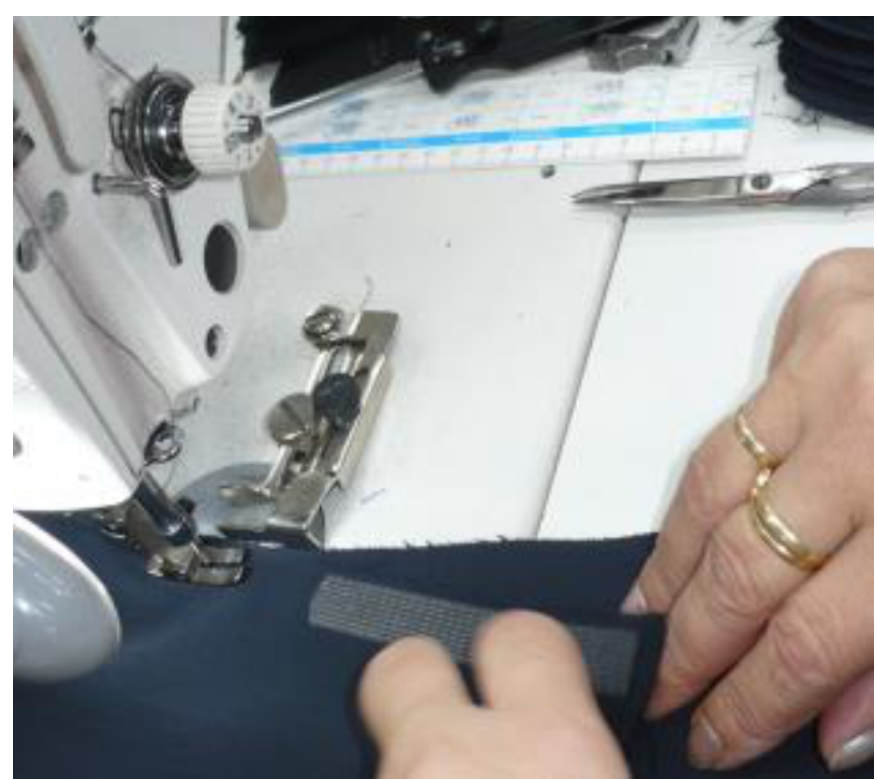

Slika 9. Provjera parametara šava nakon podešavanja vodilica šivaćeg stroja

Tablica 6. Pregled ključnih podataka o troškovima prije investicije, potrebnim ulaganjima I ostvarenim uštedama pri radu pogonskih elektromotora i rasvjete[6]

\begin{tabular}{|c|c|c|c|c|c|c|c|c|c|c|c|c|c|}
\hline & $\begin{array}{l}\text { Sati } \\
\text { rada }\end{array}$ & $\begin{array}{c}\text { Rasvjeta } \\
900 \text { LED } \\
\text { cijevi }\end{array}$ & $\begin{array}{c}\text { Kompres } \\
\text { komprim. } \\
\text { Zraka }\end{array}$ & $\begin{array}{l}\text { Centrif. } \\
\text { pumpe }\end{array}$ & $\begin{array}{l}\text { Centrif. } \\
\text { pumpe }\end{array}$ & $\begin{array}{c}\text { Rashlad. } \\
\text { toranj }\end{array}$ & $\begin{array}{c}\text { Napojna } \\
\text { pumpa } \\
\text { par.kotla }\end{array}$ & $\begin{array}{c}\text { Napojna } \\
\text { pumpa } \\
\text { par.kotla }\end{array}$ & $\begin{array}{l}\text { Klima } \\
\text { komore }\end{array}$ & $\begin{array}{l}\text { Klima } \\
\text { komore }\end{array}$ & $\begin{array}{l}\text { Vakum } \\
\text { pumpa }\end{array}$ & $\begin{array}{l}\text { Vakum } \\
\text { pumpa }\end{array}$ & Ukupno \\
\hline & 350 & & $2 \times 75 \mathrm{~kW}$ & $2 \times 7,5 \mathrm{~kW}$ & $2 \times 11 \mathrm{~kW}$ & $2 \times 11 \mathrm{~kW}$ & $4 \mathrm{~kW}$ & $3 \mathrm{~kW}$ & $2 \times 18,5 \mathrm{~kW}$ & $2 \times 5 \mathrm{~kW}$ & $30 \mathrm{~kW}$ & $18,5 \mathrm{~kW}$ & \\
\hline 0 & & 1 & 2 & 3 & 4 & 5 & 6 & 7 & 8 & 9 & 10 & 11 & 12 \\
\hline $\begin{array}{l}\text { Sadašnja potrošnja električne } \\
\text { energije u kWh ( } 350 \text { sati rada) }\end{array}$ & & 18270 & 49000 & 5250 & 7700 & 7700 & 1330 & 1015 & 12250 & 3360 & 9800 & 6125 & 121800 \\
\hline Sadašnja angažirana snaga u kW & & 52,2 & 140 & 15 & 22 & 22 & 3,8 & 2,9 & 35 & 9,6 & 28 & 17,5 & 348 \\
\hline $\begin{array}{l}\text { Sadašnji trošak el. Energije } \\
\text { (potrošnja+snaga) u Kn }\end{array}$ & & 13311 & 35700 & 3825 & 5610 & 5610 & 969 & 739,5 & 8925 & 2448 & 7140 & 4462,5 & 88740 \\
\hline Ulaganje u opremu u Kn & & 329400 & 95000 & 8000 & 14400 & 14400 & 4100 & 2900 & 19000 & 5300 & 22000 & 18000 & 532500 \\
\hline Trošak izrade & & 18000 & 5500 & 1200 & 2000 & 2000 & 1200 & 1000 & 2500 & 1600 & 5000 & 2100 & 42100 \\
\hline Sveukupno ulaganja Kn & & 347400 & 100500 & 9200 & 16400 & 16400 & 5300 & 3900 & 21500 & 6900 & 27000 & 20100 & 574600 \\
\hline $\begin{array}{c}\text { Buduća potrošnja el.energije u } \\
\text { kWh }\end{array}$ & & 7560 & 40600 & 4550 & 6475 & 6475 & 1190 & 910 & 10850 & 2940 & 8400 & 5425 & 95375 \\
\hline Buduća angažirana snaga u kW & & 21,6 & 116 & 13 & 18,5 & 18,5 & 3,4 & 2,6 & 31 & 8,4 & 24 & 15,5 & 272,5 \\
\hline $\begin{array}{l}\text { Budući trošak el. Energije } \\
\text { (potrošnj+snaga) u Kn }\end{array}$ & & 5508 & 29580 & 3315 & 4717,5 & 4717,5 & 867 & 663 & 7905 & 2142 & 6120 & 3952,5 & 69487,5 \\
\hline Ušteda mjesečno u kunama & & 7803 & 6120 & 510 & 892,5 & 892,5 & 102 & 76,5 & 1020 & 306 & 1020 & 510 & 19252,5 \\
\hline $\begin{array}{c}\text { Vrijeme povrata ulaganja (mjeseci } \\
\text { sa dvije smjene rada) }\end{array}$ & & 44 & 17 & 18 & 18 & 18 & 52 & 51 & 21 & 23 & 27 & 40 & \\
\hline
\end{tabular}




\subsection{Treća tvrtka}

1954. g. osnovana je tvrtka za prikupljanje, sortiranje i preradu tekstilnog otpada, a od 1955. g. posluje pod imenom Regeneracija. Već 1964. g. instalirana je prva linija za proizvodnju netkanog tekstila na bazi regeneriranih tekstilnih vlakana iz vlastite proizvodnje. Od 1968. g. koristi se logotip - dva vuka koji trgaju krpu, kao simbol stroja za trganje " WOLFER“ (sl 10).

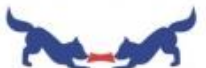 \\ regeneracija}

Slika 10. Logotip Regeneracije - dva vuka koji trgaju krpu

Proizvodnja tepiha pokrenuta je 1967.g, a 1990.g. Regeneracija je u Guinnessovoj knjizi rekorda upisana kao proizvođač najveće tapiserije na svijetu površine 1242 m2. Usmjerenost na zaštitu okoliša i energetsku učinkovitost je dokazana 1989. g. instalacijom prve i jedine pirolitičke spalionice tekstilnog otpada u regiji. Rat i njegove posljedice (raspad tržišta, izgubljene tvrtke u BiH i Srbiji, prelazak na ratnu proizvodnju) doveli su 1990-tih Regeneraciju na sam rub opstanka. Uspješno je provedena privatizacija od strane zaposlenika i strateških partnera iz Njemačke 2005. g. Posljedice toga su rast izvoza, popunjenost proizvodnih kapaciteta, osnivanje Regeneracije $\mathrm{GmbH}$ u Waiblingenu 2008. g. i preuzimanje tvrtke CO DESIGN 2014. g.

MISIJA

Isporučivati inovativna $i$ kreativna rješenja za tople i udobne prostore uz snažan doprinos očuvanju okoliša

VIZIJA

\begin{tabular}{|c|c|c|c|}
\hline $\mathbf{S}$ & $\mathbf{M}$ & $\mathbf{A}$ & $\mathbf{R}$ \\
\hline U & 0 & $\mathbf{R}$ & $\mathbf{E}$ \\
\hline S & B & $\mathrm{T}$ & C \\
\hline $\mathbf{T}$ & I & & $Y$ \\
\hline A & L & & C \\
\hline 1 & I & & L \\
\hline $\mathrm{N}$ & $\mathbf{T}$ & & I \\
\hline A & $Y$ & & $\mathrm{~N}$ \\
\hline B & & & G \\
\hline & & & \\
\hline & & & \\
\hline & & & \\
\hline & & & \\
\hline & & & \\
\hline
\end{tabular}

Slika 11. Misija i vizija Regeneracije[7]

\subsubsection{Upravljanje proizvodnim procesima u Regeneraciji}

Politika kvalitete, okoliša i zdravlja i sigurnosti na radu predstavlja temeljn dokument tvrtke Regeneracija d.o.o. u upravljanju poslovnim procesima, a koji se očituju i kroz samu misiju tvrtke - isporučivati inovativna i kreativna rješenja za tople i udobne prostore uz snažan doprinos očuvanju okoliša (sl. 11). Usvajanjem normi ISO 9001:2015 i ISO 14001:2015 i OHSAS 18001:2007 preuzeta je obveza kontinuiranog unapređivanja i poboljšanja sustava upravljanja kvalitetom, sustava upravljanja okolišem i sustavom zdravlja i sigurnosti na radu. Neprestano unapređenje kvalitete proizvoda i poslovnih procesa te orijentacija na zadovoljstvo kupaca nameće se kao osnovni prioritet u kojeg su uključeni svi zaposlenici tvrtke. Kako bi se to postiglo, zaposlenicima je osigurano cjeloživotno učenje i usvajanje novih znanja kao jedinu garanciju za mogućnost dugoročnog ostvarenja životnih

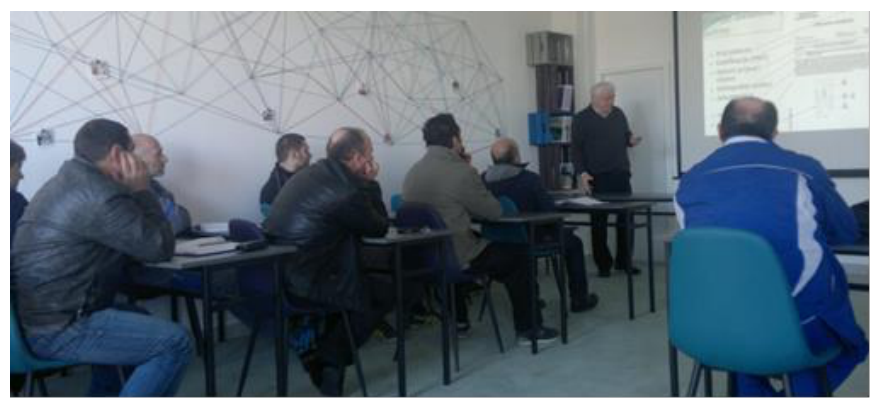

Slika 12. Predavanja u okviru Plana cjeloživotnog učenja zaposlenika Regeneracije ciljeva (sl.12). Kao tvrtka koja, između ostalog, svoje poslovanje temelji na načelima društvene odgovornosti, zaštitu na radu, zdravlje i sigurnost na radu postavljeno je kao jedan od glavnih ciljeva koji je prisutan 24 sata na dan. Svaka nova investicija i tehnička rješenja, uz doprinos kompetitivnosti tvrtke, u funkciji su povećanja razine sigurnosti na radu, zdravlja zaposlenih i zaštite od požara. Organizacija poslovnih procesa provodi se prema načelima održivog razvoja, zbog čega se nastoji racionalno koristiti ljude, sve vrste energenata $i$ smanjivati in $u$ odnosu na jedinicu gotovog proizvoda, istovremeno imajući u vidu što manji utjecaj na okoliš. U skladu sa suvremenim trendovima, želja je dugu tradiciju, znanje i iskustvo u prikupljanju i recikliranju tekstilnih materijala (sl. 13) te njegovu ponovnu uporabu staviti u funkciju ukupnog gospodarenja otpadom te uspostaviti model koji će, uz snažan doprinos očuvanja okoliša, osigurati dugoročno profitabilno poslovanje.[8]

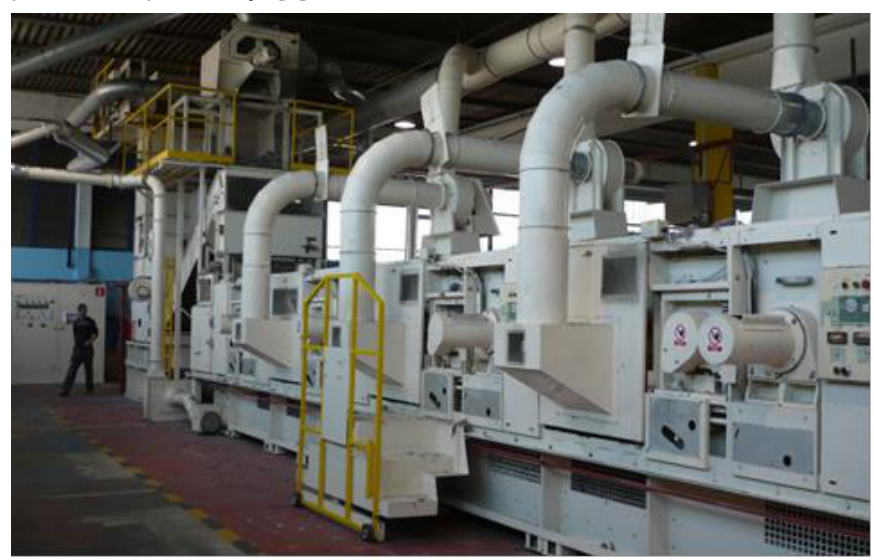

Slika 13. Postrojenje za recikliranje (rahljenje) tekstila

\subsubsection{Proizvodnja tepiha}

Značajna djelatnost u Regeneraciji je i izrada visokokvalitetnih tepiha temeljenih na vrhunskoj kreativnosti dizajnera i arhitekata čime se omogućuje personalizacija tepiha u okviru prostornih zadatosti svakog projekta, gdje tepih afirmira dotični interijerski identitet (sl.14).

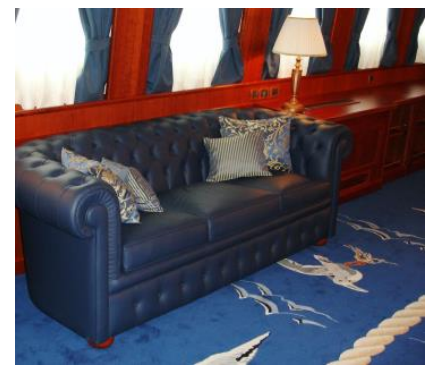

a)

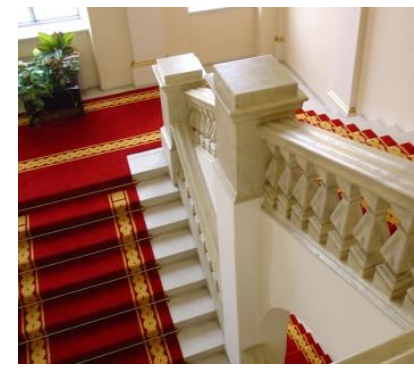

b)
Slika 14. Tepisi: a) U jahti,Seagull II“, b) Stepenice u Saboru Republike Hrvatske[9]

Proizvodnja taftanih tepiha je složen proces, posebno zbog toga što je kupcima potrebno udovoljiti kvalitetnom vunenom pređom odgovarajućih karakteristika i boje. Zbog toga je nužna kvalitetna, odgovarajuća bojadisaonica koja je projektirana i izgrađena u skladu sa zahtjevima struke.(sl.15).

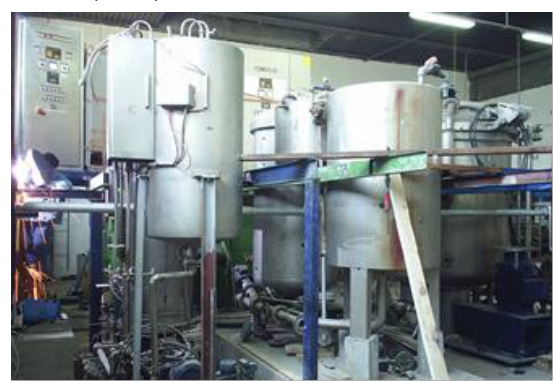

a)

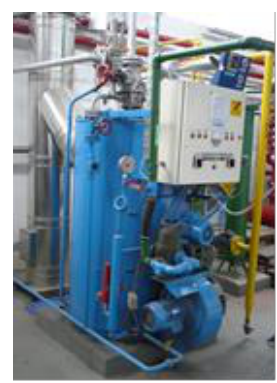

b)
Slika 15. a) Montaža bojadisaonice, b) kotao za brzu proizvodnju vodene pare

$\mathrm{U}$ bojadisaonici vunene pređe i vlakana vunenog tipa propisanih karakteristika odvijaju se tehnološki procesi: pranje, bijeljenje, bojenje, centrifugiranje, filcanje (pustenje), sušenje. Za izvođenje tih procesa 
potrebno je: tehnološka voda, vodena para, električna energija, plin, zrak pod pritiskom, strojevi i uređaji pomoću kojih se ostvari zadani cilj, radna snaga, prostor (okoliš) i propisani uvjeti za nesmetan rad radnika (osvjetljenje, temperatura, vlaga, prozračnost bez propuha...) Povođenjem tehnoloških procesa potrebno je voditi brigu o mnoštvu elemenata: kvalitet proizvoda, količini proizvoda, utrošku energije i mogućnost uštede, utrošku sirovine i pomoćnih materijala, utrošku vode, pročišćavanje otpadnih voda, povrat vode u proces, zaštiti okoliša (minimalno zagađenje u skladu sa propisima) Osim bojadisaonice, u novim prostorima postavljeni su (u skladu s pripremljenim projektima) dvanaest metarski okviri (visine $3 \mathrm{~m}$ ) na kojima se napinje tkanina za ručno taftanje. Također je uređen prostor za lateksiranje i doradu tepiha.

\subsubsection{Vođenje procesa održavanja u Regeneraciji}

Cjelokupna rekonstrukcija izvedena je bez većih zastoja u proizvodnji odnosno, sve je bilo usklađeno, tako da prema kupcima nije bilo nikakvih korekcija rokova isporuke. Razvidno je da u procesima rekonstrukcije izgradnje novih proizvodnih pogona na drugim lokacijama i istovremeno usavršavanje, moderniziranje s vlastitim inovativnim idejama bio potreban veći broj stručnjaka iz različitih područja. Zbog jednostavnijeg snalaženja boljeg uvida u svakom trenutku na svakoj poziciji, izrađen je pomoćn računalni program. Ujedno je ubrzan postupak evidencije zastoja, radova, nadomjesnih dijelova i svega što je potrebno da se konačno obračunaju svi troškovi, te oblikovani podaci za zapisnik o primopredaji i obrazac o pregledu zastoja za svaki stroj. Pri svakoj proizvodnoj liniji nalazi se računalo s kojim se prati proizvodni proces, unose se svi relevantni podaci, pa tako i vrijeme početka zastoja, vrijeme poziva majstora održavanja, ponovnog pokretanja itd. Važno je napomenuti da je sve povezano s računalima rukovodioca, koji su u svakom trenutku upoznati s podacima iz proizvodnje, te po potrebi mogu intervenirati.

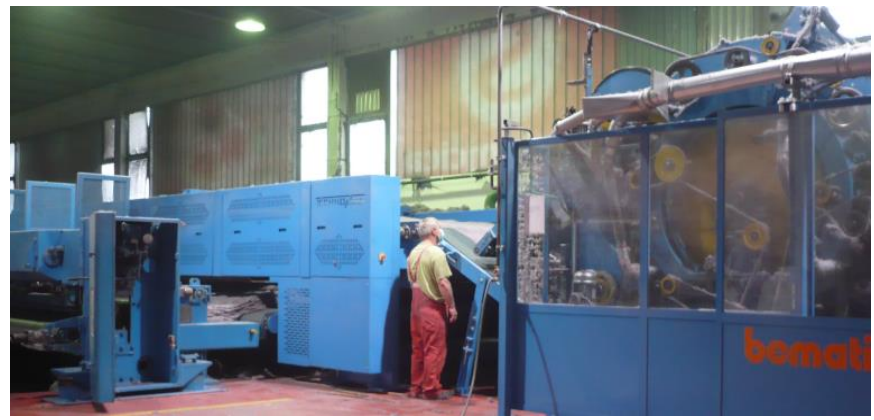

Slika 16. Linija za proizvodnju vate iz regeneriranih vlakana

U skladu s prethodno spomenutim normama, usvojenim i preuzetim obvezama kontinuiranog unapređivanja i poboljšanja sustava upravljanja kvalitetom, a zbog složene opreme u proizvodnji (sl.16) potrebno je da svaki učesnik tima dosljedno odrađuje preuzetu obvezu. Dodatni problem je velika količina lebdećih kratkih vlakana koja se oslobađa za vrijeme obrade na pojedinim dijelovima vlačara, polaganja koprene na polagačima, te iglanja runa između perforiranih dasaka stroja za iglanje (sl.17).

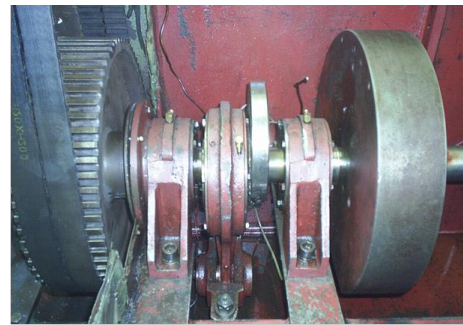

a)

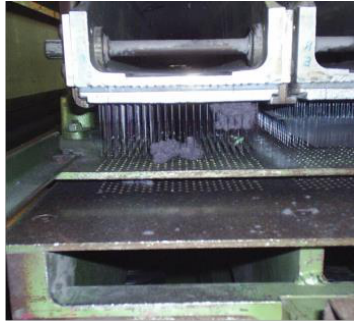

b)
Slika 17. Dijelovi stroja za iglanje: a) Pogon glavnog vratila zupčastim remenom i remenicom, zamašnjak, klizni ležajevi podmazivani uljem pod pritiskom, ekscentar s ojnicom za stvaranje vertikalnog pomaka daske s iglama, b) daske s iglama iznad gornje i donje perforirane daske

Sve je opisano u procedurama. Linijama rukovode i poslužuju ih stručne osobe koje reagiraju i na najmanju promjenu, devijaciju za vrijeme proizvodnje (reagiraju i na promjenu zvuka za vrijeme rada). Propisana su tri intervala servisa: A interval: svakih pet do sedam dana pojedini stroj zaustavi te se na njemu očiste svi vanjski vidljivi dijelovi stroja $B$ interval (jednom mjesečno ili ukoliko se ukaže potreba i češće), radi se sve kao u A intervalu s time da se podmazuju i vanjski vidljivi dijelovi stroja. $C$ interval (svakih šest mjeseci ili ukoliko je potrebno i prije) obuhvaća zahvate A i B interval i podmazivanje svih dijelova, te ukoliko je planom remonta predviđeno promjenu pojedinih dijelova stroja ili cjelokupni remont stroja. $U$ skladu s pozitivnom praksom, višegodišnjim iskustvima i preporukama proizvođača strojnih dijelova izrađuju se godišnji planovi remonta kojim se uklone mogućnosti „slučajnih“ kvarova uslijed pohabanosti ili pucanja slijedom zamora materijala, te pojava kvara (sl.18) u nezgodnim trenucima s eventualno tragičnim posljedicama.[10]

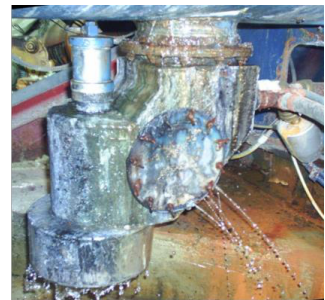

a)

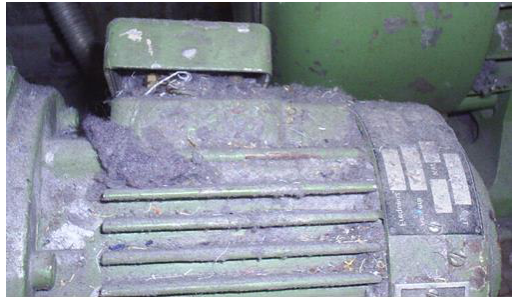

b)
Slika 18. a) Voda probila brtvu na cirkulacionoj pumpi aparata za bojadisanje, b) nakupine kratkih vlakana sprječavaju cirkuliranje zraka između rebara za hlađenje elektromotora

\section{Zaključak}

Održavanje strojeva, opreme treba se promatrati kao komponenta proizvodnog procesa i treba biti prilagođeno proizvodnji s ciljem što manjeg neplaniranog prekida proizvodnje. Održavanje treba promatrati kroz tri segmenta: preventivno, interventno i investicijsko, a potrebno ga je isplanirati tako da je težište na preventivi i investicijskom održavanju, a interventno tijekom vremena smanjiti. Bez obzira na različite proizvodne procese, pristup i strategije održavanja proizvodnih strojeva i opreme u tri analizirane tvrtke, uočava se potreba organiziranja kvalitetnog održavanja i da postoji interes da se svaka aktivnost, svakog djelatnika usmjeri prema već spomenutom cilju - osiguranju kvalitetnije proizvodnje sa što manje neplaniranih zastoja i što manjim troškovima u čemu velik udio ima dobro gospodarenje energijom. Velik doprinos mogu dati stručnjaci održavanja pri izboru energetskih postrojenja, a za vrijeme životnog vijeka opreme primjenjivati suvremene pristupe koji će osigurati veliku iskoristivost, kvalitetu i profitabilnost.

\section{Literatura}

[1] http://www.fsb.unizg.hr: Čala, I.: Održavanje, Uvod u održavanje opreme, prezentacija, Sveučilište u Zagrebu Fakultet Strojarstva i brodogradnje, Zagreb, 2005./, Pristupljeno: 2020-02-02

[2] Bischof S., Knezić Ž.: Vođenje procesa oplemenjivanja, Prezentacija radni listovi i bilješke s predavanja, 2019.

[3] Procedura: Održavanja, Regeneracija d.d. u skladu sa sustavom za kvalitetu ISO 9001:2000, Regeneracija d.d. Zabok, 2006.

[4] Knezić Ž. i sur.: Kvalitetno održavanje postrojenja u funkciji proizvodnog procesa u tekstilnoj industriji, Tekstil, 62 (2013) , 9-10, 370-379

[5] Knezić Ž., Penava Ž., Tratnik M.: Utjecaj plana proizvodnje i aktivnosti poslužitelja tkalačkih strojeva na produktivnost, Zbornik radova: 5 . međunarodno znanstveno-stručno savjetovanje Tekstilna znanost i gospodarstvo / Ujević, Darko; Penava, Željko (ur.), Zagreb: Sveučilište u Zagrebu, Tekstilno-tehnološki fakultet, 2012. 245-250 (poster, međunarodna recenzija, objavljeni rad, znanstveni), ISSN 1847-2877

[6] Knezić Ž. i sur.: „KOTKA“ konfekcija d.d. Krapina - Povećanje energetske učinkovitosti, Krapina 2010.

[7] https://www.regeneracija.hr/index.php/hr/onama-regeneracija-hr/misijai-vizijaregeneracija/, Pristupljeno: 2020-02-02 [8] https:// www.regeneracija.hr/index.php/hr/onama-regeneracija-hr/povijest/, Pristupljeno: 2020-02-02

[9]https://www.regeneracija.hr/index.php/hr/galerije/turisticki-iposlovniobjekti\#!DSC00505, Pristupljeno: 2020-02-02

[10] Knezić Ž., Brlečić M.: Smanjenje požarnog rizika edukacijom djelatnika i kvalitetnim održavanjem postrojenja u tekstilnoj industriji, Zbornik radova: IX stručni skup vatrogasaca, Vatrogasna zajednica Primorskogoranske županije, Opatija, Hrvatska, 25. - 26. travnja 2013. 